\title{
Atracção Química
}

O lançamento do Programa Atracção Química pressupunha que este se iria construindo a partir de um conjunto inicial de actividades, às quais se iriam progressivamente juntando todas as outras que a $\mathrm{SPQ}$ pudesse levar a cabo em colaboração com os Departamentos de Química das universidades, as Escolas e a Sociedade em geral. O acompanhamento desta evolução da Atracção Química pelos sócios, far-se-á pela divulgação regular das actividades no "sítio" da SPQ e no boletim "Química". Uma presença regular que se inicia neste número.

\section{Breve referência às actividades já anunciadas}

Quando este número chegar aos sócios, ter-se-ão já realizado as Olimpíadas de Química Júnior (ver Noticiário SPQ). Os resultados finais desta iniciativa só poderão ser avaliados a médio / longo prazo, mas o grau de satisfação de professores e alunos dará um indicador mais imediato da sua relevância na vida das escolas.

Está planeado para estas Olimpíadas a distribuição dos primeiros folhetos de promoçăo da Química como disciplina de estudo e opção profissional. Espera-se que o teste "Tens queda para a Qurmica?", baseado num folheto similar da Royal Society of Chemistry (Reino Unido), possa dar aos participantes uma outra visão da Química.

Entretanto, continua a renovação profunda, embora ainda pouco visível, do "sítio" www.spq.pt, que se pretende que dê âos sóciós e às futurās Direcçõés dá SPQ uma plataforma de trabalho ímpar para apoio às suas actividades.

\section{Novas actividades}

A Quimica na Internet - a importância da internet como fonte de informação para os mais jovens nẫo pode ser ignorada. Actualmente, a busca na internet substitui de forma sistemática a consulta de um dicionário, de uma enciclopédia, de um livro de texto... (mesmo para aqueles que nunca tiveram hábitos de consulta destas fontes de informação!) O problema está, é claro, na ausência de filtros que garantam a qualidade da informação obtida. Este problema pode ser parcialmente ultrapassado pela criação de um número elevado de "sítios" fidedignos, havendo, portanto, todo o interesse em aumentar o número de páginas de Química em português na internet.

Assim, a SPQ convidou os DQS das Universidades a criarem nos seus "sítios", páginas especificamente dedicadas à divulgação da Química (como ciência e como actividade profissional) dirigidas aos jovens dos 10 aos 17 anos. Quem ja visitou as páginas dos DQs sabe que é fácil encontrar informação institucional, mas dificil encontrar conteúdos (e concepções gráficas) destinados aos jovens. Como estímulo, a SPQ pretende instituir um sistema de prémio e divulgação destas páginás.

Os Dias da Química - a organização de actividades de divulgação dos DQS, durante os Dias Abertos, Semana da Ciência, e similares, é fortemente encorajada pela SPQ. No entanto, apesar da realização destas iniciativas ser já rotineira em algumas instituições, não há um siste- ma de troca de informações, partilha de experiências, e avaliação de resultados. Deste modo, a SPQ estabeleceu com o DQ da UNL uma parceria-piloto para o desenvolvimento destas actividades. O Dia da Química, realizado a 3 de Março, foi o primeiro passo para a criação de um fórum de actividades de divulgação e promoção da Química entre os jovens.

IV DEDQ - ós Encontrós dã Divisăõo de Ensino e Divulgação da Química sempre mereceram uma atenção especial da(s) Direcção(ões) da SPQ. Depois de 2 edições na Universidade de Aveiro, e do III DEDQ no Porto, Griou-se uma indefinição quanto ao futuro. Face a esta situação, a Direcção decidiu assumir a realização do IV DEDQ, considerando-o como uma iniciativa de importância estratégica, com um papel relevante na promoção da Química nas Escolas.

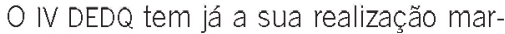
cada para os dias 26 e 27 de Outubro próximo, no Parque das Nações, em Lisboa (ver Tomar Nota), passando a integrar o Programa Atracçăo Química. Fazendo jus ao nome da Divisão, o programa do Encontro devera incluir componentes de Ensino e de Divulgaçăo da Química. Um projecto para provocar uma forte Atracção Química.

\footnotetext{
* Coordenador da Olimpíadas de Química da SPQ, (pclaro@dq.ua.pt)
} 


\section{Ensino: uma questão política enredada num absurdo científico ${ }^{1}$}

Resumo A reflexão que segue visa equacionar alguns dos problemas estruturais do ensino básico e secundário em Portugal no início d século XXI. Incidirá em quatro pontos:

I - A ideologia em forma de ciência;
II - A escola e a regulação de relações entre pessoas;

III - O sistema de avaliação como reflexo da escola que temos;

IV - O dilema da função docente: servir o aluno ou servir o conhecimento?

\section{I - A ideologia em forma de ciência}

A escola vive uma grave crise de identidade enquanto espaço social simbólico. Para tentar ultrapassar isso será necessário romper com a ideologia «anti-conhecimento" que domina o sistema escolar, perfeitamente espelhada nas correntes dominantes das auto-denominadas «ciências da educação» e na cultura hedonista que as caracteriza e que ganhou forte expressão social

Este é o mais importante nivel em que se tem de situar o problema da crise cultural, seja cientifica, seja humanista. A essência do problema reside, sem dúvida, nos decisivos ensinos básico e secundário.

Parece-me óbvio que os três pilares em que assenta (e sempre assentou) o sistema de ensino são:

\section{9) o conhecimento; \\ 2. ${ }^{\circ}$ ) professor; \\ 3.') e o aluno.}

Nấo é por acaso que os coloco por esta ordem.

De modo nenhum pretendo desvalorizar qualquer deles, mas tão só mostrar que é um erro não tomar o conhecimento como o «sector de ponta» do sistema de ensino e, como consequência, será também um erro não considerar o professor, antes e acima de tudo, como um transmissor de conhecimentos. Ensino básico quer dizer precisamente isso: transmitir saberes elementares, algo em que se tem sistematicamente falhado. Cumprida essa funçăo, o professor pode ser tudo o resto.

É um erro grave, particularmente no ensino básico, considerar o professor, em primeiro lugar, como um animador de aprendizagens ou de auto-aprendizagens dos alunos. Essa deriva visionária da função docente tem de ser invertida.

A raiz do desastre está precisamente nas paranóicas pedagogias activas centradas no aluno

Parece evidente que o problema do ensino é e sempre foi um problema político, concretamente um problema ideológico. Para se fugir a essa dimensão incómoda, precisamente porque não se tem sabido lidar com ela dada a inabilidade das utopias em lidar com o contraditório, criou-se um mecanismo ilusório para erradicar a dimensão política ou ideológica do ensino que está a ter efeitos gravemente perversos.
Ele deixou o ensino e, portanto, a essência do nosso projecto de sociedade, nas mãos de uma minoria supostamente iluminada.

Essa minoria iluminada agrega-se em torno das ditas ciências da educação. Ao tentarem tornar científico o que é político - ou, na melhor das hipóteses, o que é cultural, do bom senso, do senso comum, da tradição de ensinar, do domínio da opinião, do livre debate de pontos de vista - as ciências da educaçăo acabaram por ter o efeito de radicalizar a dimensăo política, tornando o nosso ensino dogmático e muito colado à conjunturả revooluciơnária dós anoós 70 em que foi moldado?

O grave é que isso está a ser feito de modo inconsciente, numa espécie de "caldo de cultura política monolítica" que vai acumulando sucessivas vitórias contra o conhecimento, precisamente no núcleo duro onde isso jamais deveria acontecer: no sistema de ensino.

O que há de saberes académicos ou científicos no ensino (refiro-me, em particular, ao ensino básico e secundário) são as ápeas disciplinares - o português, a matemática, a história, a geografia, a filósoofiả, à físicà, à químiçả, etć. - e nunca uma visão global sobre o ensino.

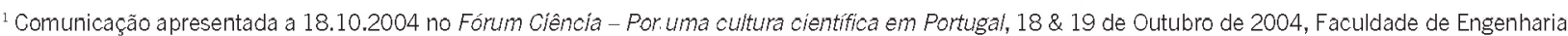
da Universidade do Porto.

* Professor de Histórià do ensino secundário - Almada (mitharibeiro@net.sảpo.pt) 